\title{
REVISITING STUDENTS' ENTREPRENEURIAL INTENTION IN INDONESIA: A THEORY OF PLANNED BEHAVIOR APPROACH
}

\author{
Ambara Purusottama \\ Universitas Prasetiya Mulya, BSD City Kavling Edutown, Tangerang, Banten 15339 \\ Email: ambara.purusottama@pmbs.ac.id
}

\begin{abstract}
The purpose of this study is to verify and measure entrepreneurial intentions among university students as affected by changes in the entrepreneurial environment in Indonesia. The researchers use the Theory of Planned Behavior and the concept of entrepreneurial intention to support the study. The unit of analysis is university students who are currently exposed to changes in the entrepreneurial environment. This study uses a quantitative approach with purposive sampling as the sampling technique. The questionnaire was distributed, and 631 sample responses were received from several universities. The findings show that attitude and perceived control behavior have a significant role in entrepreneurial intention. In addition, subjective norm plays no role in entrepreneurial intention.
\end{abstract}

Keywords: Entrepreneurial environment, theory of planned behavior, entrepreneurial intention, university student

\section{Introduction}

The government has implemented compulsory entrepreneurial education to encourage entrepreneurial competitiveness in Indonesia and promote the national economy. A study by Urbano and Aparicio (2016) proved that entrepreneurship is the preferred instrument to leverage the country's economy. Entrepreneurship education in Indonesia focuses on the tertiary level; a study by Veciana, Aponte, and Urbano (2005) showed that students had the potential to drive entrepreneurship, and the introduction of entrepreneurship education would be more effective if implemented in an early age. Entrepreneurship education is emphasized through the National Education Standards (Standar Nasional Pendidikan, SNP), which must be followed by all officially registered universities. The implementation of entrepreneurship education is adapted according to the scientific field, developed in a lecture curriculum, or included as a curriculum complement.

Studies of entrepreneurial intentions have attracted many researchers' interest, especially researchers based on entrepreneurship education centers. Souitaris, Zerbinati, and Al-Laham (2007) and Liñán, Rodríguez-Cohard, and Rueda-Cantuche (2011) emphasized that entrepreneurial intentions were strongly influenced by support from the surrounding environment, such as ecosystems and education. The inputs that affect student entrepreneurial intentions are still difficult to determine in Indonesia. The findings of Kristiansen and Indarti (2004), who studied entrepreneurship intentions in Indonesia, are no longer relevant; the entrepreneurial encouragement during their research period was not as strong as it is today.
Kusmintarti, Asdani, and Riwajanti (2017) analyzed the entrepreneurship intentions of Indonesian students, but they used a different variable approach: attitude and creativity. Therefore, it is important to conduct new research on student entrepreneurial intentions in Indonesia by considering the currently developing situation with the support of a more comprehensive theory of organizational behavior.

The development of entrepreneurship encourages many researchers to compete in conducting studies from the perspective of organizational behavior, such as Ajzen (1991), Krueger and Brazeal (1994), and Shapero and Sokol as cited by Zhang, Duysters, and Cloodt (2013). The rapid development of behavioral theory in the field of entrepreneurship has attracted researchers to compare the models presently considered the most relevant (Krueger, Reilly, \& Carsrud, 2000). The theory of entrepreneurial behavior is basically a development of the theory of organizational behavior that aims to determine individual behavior in entrepreneurship. However, because behavior is difficult to measure, most researchers use entrepreneurial intentions as compared to entrepreneurial behavior. Scholars have stated that entrepreneurial intentions are more predictable and are considered capable of representing behavior because such a process is followed before actions are taken (Turker \& Selcuk, 2009). The concept of intention in entrepreneurship is very important because it is a predictor of entrepreneurial activity: as such, it compensates for the research limitations in studying entrepreneurial behavior.

Krueger et al. (2000) stated that the testing of two models, the Theory of Planned Behavior (TPB) and the Entrepreneurial Potential Model (EPM), gave 
relatively similar results in the context of entrepreneurial intentions but the results of EPM were more significant than those of TPB. However, TPB is more attractive to researches because it can function across cross-disciplinary fields and provide a more comprehensive understanding of behavior. By adopting TPB, this study tries to measure the implications of entrepreneurial encouragement for university students. In addition, the study expects to find the determinants that encourage entrepreneurial intention among students. This study was conducted empirically using a sample of university students exposed to entrepreneurship in Indonesia.

\section{Entrepreneurial Intention Model}

Study of entrepreneurial intention has attracted many researchers. Three models have been developed to test entrepreneurial intention: TPB, EPM, and Entrepreneurial Event Theory (EET). TPB focuses on organizational or individual behavior that is influenced by three main factors: Attitudes (ATT), Subjective norm (SUB), and Perceived Behavioral Control (PBC).

Some models of entrepreneurial intention have been developed because there is no fundamental measurement tool for studying entrepreneurial behavior. TPB was developed by Icek Ajzen in 1991 as an improvement of the Theory of Reasoned Action (TRA), which was developed to study the behavior of individuals or organizations. TPB has succeeded in becoming an essential instrument to measure human behavior across scientific clusters, including entrepreneurship. EPM is a development of entrepreneurship science and was proposed by Krueger and Brazeal (1994). It encourages the use of perceived desirability, perceived feasibility, and the tendency to act on opportunities. EET is an entrepreneurial theory that aims to explain entrepreneurial intentions and understand behavior better.

Krueger et al. (2000) compared the two theories of entrepreneurial intentions, EET and TPB, and found that EET gives better results compared to TPB. However, TPB was chosen in this research because it has been tested across scientific clusters.

\section{Theory of Planned Behavior}

TPB was developed to study the behavior of humans and organizations and the consequence of their dynamics. This theory is an extension of the previous theory, TRA, which considers human behavior to be influenced by two factors: the internal and external. Internal is an individual's attitude, which comes from the experience and insight that the individual possesses; the external is the influence of the social environment on the individual. The contribution of TPB was studied empirically by Armitage and Conner (2001), and the results can effectively be used for studying various forms of behavior. TPB comprises three interconnected main factors: Attitudes, Subjective norm or social environment, and behavioral controls, which is a novel addition developed from previous theories (Ajzen \& Sheikh, 2016).

Attitude belief is an individual's assessment of the consequences of actions taken (e.g., good/ bad, beneficial/less useful). Attitude confidence is driven by a series of experiences and the insights the individual has (Fayolle \& Gailly, 2015). Attitude is measured by two indicators: experiential and instrumental attitude (Ajzen, 2005). Experiential attitude is essentially an affective overall evaluation of a behavior experienced previously. Actions performed will be noted by individuals and evaluated as being either positive or negative. If the action results are considered good, the individual will give a positive signal, and vice versa. Instrumental attitude is the result of something learned by individual. In the context of entrepreneurship, experiential and instrumental attitude are the experience and translation of that experience individuals in conducting entrepreneurial activities. If the experience and translation of entrepreneurship are considered good and provide benefits, the individual will give a positive response, and vice versa (Peng, Lu, \& Kang, 2012).

Normative beliefs are individual judgements based on the opinions of the surrounding social environment. Ajzen (2005) described the social environment in question as the people who have close relationships with these individuals, such as family, friends, and role models; these people can influence the decisions made. To understand and measure subjective norm, normative trust and motivation to comply are used. Fayolle and Gailly (2004) used normative belief indicators to measure the effect of judgments from other people who are trusted (referenced) on the behavior performed. The assessment of the referenced person may approve or disapprove of the behavior performed. If the reference considers the behavior as not in accordance with the values adopted or trusted, he or she will give a negative response, and vice versa.

Motivation to comply is the motivation of individuals to do what the reference thinks they should. As an application in entrepreneurship, if the reference points to something as good, he or she will give a positive response to the individual, and vice versa. In Indonesia, unpopular entrepreneurship will affect the 
reference's assessment of individuals (Liñán et al., 2011). Therefore, it is very important for individuals who will be entrepreneurs to seek an environment that supports their entrepreneurship.

Perceived behavioral control is a factor that aligns intentions and actions with the presence of resources and opportunities (Ajzen, 2005). The more resources and opportunities, the higher the behavioral control. Perceived behavioral control can be measured through control belief and perceived power. Armitage and Conner (2001) explained control belief as a psychological concept close to self-efficacy, serving as something that encourages or discourages an action as a result of its limitations. If an individual has greater limits, control belief will be debilitating; if the limitations are considered low, it will be empowering. The limitations referred to in entrepreneurship are not only in tangible resources, but also include invisible resources. Perceived power refers to how individuals respond to the difficulty of a behavior. If the individual views the behavior as difficult to perform, he or she will respond negatively, and vice versa. In practice, in entrepreneurship, perceived behavioral control is an instrument for linking entrepreneurial intention and entrepreneurial behavior (Fayolle \& Gailly, 2004; Zhao, Seibert, \& Hills, 2005).

\section{Entrepreneurial Intention}

Studies on entrepreneurial intention are more developed in western countries that have entrepreneurial activity in which small companies try to reduce the economic gap between themselves and large companies (Ferreira et al., 2012; Obschonka, Silbereisen, \& Schmitt-Rodermund, 2010). Entrepreneurship studies have attracted the interest of psychology researchers to study the psychology of entrepreneurs seeking to create a new business. Researchers have tried to develop the field by combining the general psychology of entrepreneurs and the situation they face. Interest in entrepreneurship is very strong because it combines human psychology with entrepreneurial activity; entrepreneurial decisions translate to actions with strongly reasonable basis (Sheppard, Hartwick, \& Warshaw, 1988).

Descriptions of entrepreneurial interest can be found in many articles. The definition described by Ajzen (1991) claims that intention refers to "[the] indications of how hard people want to try, how much effort they plan to exert, [and] to carry out actions". Another popular description is by Krueger et al. (2000), who stated that entrepreneurial interest is the target behavior of starting a new business. Entrepreneurship intention is a belief that an entrepreneurial career is a good choice, and choosing this path will involve action oriented toward the goal of business creation (Armitage \& Conner, 2001). The entrepreneurial intention concept has been empirically tested by several researchers, such as Peterman and Kennedy (2003); Florin, Karri, and Rossiter (2016).

According to Bird (1988), entrepreneurial intention is a strategic stage in the entrepreneurial process to create a new business. Entrepreneurial intention facilitates the goals, commitment, and communication needed when businesspeople create their businesses. The intentionality process involves three main activities, namely the process of specifying, making, and maintaining, and is completed by a selection process. These three processes are structured and logical stages. A recent study stated that entrepreneurial intentions are built on two main things: passion and creativity (Biraglia \& Kadile, 2017). Entrepreneurial passion is a positive feeling experienced consciously when a person performs entrepreneurial activity in a meaningful role, confirming his or her identity as a businessperson (Cardon \& Kirk, 2015). Creativity is the development of useful new ideas as a result of interactions between individuals and their environment (Hunter, Bedell, \& Mumford, 2007).

The measurement of entrepreneurial intention is derived from entrepreneurial behavior. Armitage and Conner (2001) used three indicators to measure interest, namely desire, self-prediction, and behavioral intention. Other studies showed personal attraction to be a measure of entrepreneurial intention (Fayolle \& Gailly, 2004; Kolvereid, 1996). Although these studies had different views on determining the indicators of interest in entrepreneurship, the dimensions used were relatively similar.

Table 1

Indicators of TPB and Entrepreneurial Intention

\begin{tabular}{lll}
\hline \multicolumn{1}{c}{ Variables } & \multicolumn{1}{c}{ Indicators } & \multicolumn{1}{c}{ References } \\
\hline Attitude & - Instrumental & Ajzen, 2005; Armitage \\
& Attitude & \& Conner, 2001; \\
& - Experiential & Fayolle \& Gailly, \\
& Attitude & 2004; Kolvereid, 1996 \\
Subjective & - Normative Belief \\
Norm & - Motivation to \\
& Comply \\
Perceived & - Control Belief \\
Behavioral & - Power Belief \\
Control & \\
Entrepreneuria & - Pure Intention \\
1 Intention & - Personal \\
& Attraction \\
\hline
\end{tabular}

Understanding of entrepreneurial intention is often found to be highly related to business creation, 
both new creations and further development of existing creations, and also career selection as a businessperson. This encourages the expansion of the entrepreneurial intention indicators used. According to Armitage and Conner (2001), intention and interest are difficult to understand clearly; therefore, pure intention and person attraction are the indicators in measuring entrepreneurial intention. Details of TPB's indicators and entrepreneurial intention are given in Table 1.

\section{$T P B$, Entrepreneurial Intention and Entrepreneurship}

TPB is an instrument that has been empirically tested in various scientific fields, including entrepreneurial activity (Fayolle \& Gailly, 2015; Townsend, Busenitz, \& Arthurs, 2010; Zhao et al., 2005). Although TPB passed many tests, several have criticized and updated the theory (Armitage \& Conner, 2001). The strong influence of TPB on entrepreneurial behavior places it as a predictive theory of entrepreneurship that is used as the basis of advanced research to develop the concept of entrepreneurial behavior (Kautonen, van Gelderen, \& Fink, 2015). TPB is also used by many researchers in the context of entrepreneurship to facilitate the measurement of individual or organizational behavior. For example, in many studies, demographic and geographic characteristics were used as moderating variables to examine the entrepreneurial behavior of individuals or organizations (Küttim, Kallaste, Venesaar, \& Kiis, 2014; Maes, Leroy, \& Sels, 2014). Furthermore, TPB can evaluate different facets of the performance of entrepreneurial behavior, such as comparisons with other entrepreneurial intention models (Krueger et al., 2000), gender effects (Leroy, Maes, Sels, \& Meuleman, 2009), and nascent entrepreneurship (Nishimura \& Tristán, 2011).

One study specifically measured entrepreneurial intentions using TPB and revealed that the intention in entrepreneurship was more influenced by attitude and perceived behavioral control than by subjective norm (Moriano, Gorgievski, Laguna, Stephan, \& Zarafshani, 2011). The influence of culture in several countries influenced the view of the reference regarding entrepreneurship, which then influenced the interest of individual's in entrepreneurship. Other studies emphasized similar conditions from a gender perspective (Maes et al., 2014) and concurred that entrepreneurial intention was more influenced by attitudes and behavioral control than by subjective norm. In particular, female students had lower outcomes than men, and subjective norm proved to have no influence. Iakovleva, Nabi, Kolvereid, and Stephan (2011) compared entrepreneurial intentions in developed and developing countries. They found that entrepreneurial intention in developing countries exceeded that in developed countries. Specifically, the three variables in TPB had positive values and had a strong influence on interest in entrepreneurship. Paco, Ferreira, Raposo, Rodrigues, and Dinis (2011) found that two factors influence interest in entrepreneurship in middle-class students: attitude and behavioral control. Attitude had a more dominant influence than behavior control, and subjective norm did not have any effect.

\section{Research Hypothesis}

Attitude is a factor in an individual that is learned and produces a positive or negative response, including in entrepreneurial activities, where it is known as entrepreneurial attitude (Liñán et al., 2011). Feelings are determined by one's beliefs as based on the consequences of past actions (Ajzen \& Sheikh, 2016). Ajzen (2005) claims that attitudes represent an appraisal of psychological objects occupying the opposing negative and positive attitude dimensions. Attitudes can shift due to the valence in beliefs (Kautonen et al., 2015). In the context of entrepreneurship, ATT can be described as an individual responding positively when business brings benefits and responding negatively when it does not. On the other hand, in the professional attraction context (Souitaris et al., 2007), ATT can be explained as the desire to be selfemployed when having a business is considered to be beneficial or to remain working in an company when it is not.

$H_{a l}$ : There is a strong and positive relationship between attitude and students' entrepreneurial intention.

Subjective norm is a tool to measure social pressure to become an entrepreneur (Liñán et al., 2011). Specifically, subjective norm is the perception of the persons considered the "point of reference" who will approve the decision of whether or not one becomes an entrepreneur. TPB refers to subjective norm as the perception or opinion of other individuals who are considered important when one decides to act. The opinion of these individuals may alter one's view and motivation. As a result, subjective norm can be defined as social pressure that comes from those who are considered important when one takes action. Prior research has noted that subjective norm have an essential role in human behaviors, especially those that underlie intention and attitudes. With regard to 
entrepreneurial activities, when an individual becomes an entrepreneur, he or she will be influenced by other individuals who are considered important (Ajzen, 2005). A strong outside opinion on becoming an entrepreneur will lead an individual to follow that pressure.

$H_{a 2}$ : There is a strong and positive relationship between subjective norm and students' entrepreneurial intention.

PBC is the perception of the level of difficulty of becoming an entrepreneur (Liñán et al., 2011). Referring to TPB, PBC is the impression of the ease OR difficulty of an action as reflected by past experiences and the anticipation of future obstacles. PBC is closely related to the theory of self-efficacy developed by Bandura in 1997. Bandura describes self-efficacy as someone's belief, related to his or her ability to produce a certain level of performance, that affects events influencing that individual's life. Selfefficacy decides how individuals feel, think, inspire, and behave. Such beliefs have differing impacts through four noteworthy processes: cognitive, motivational, affective, and determination processes (Ajzen, 1991).

$H_{a 3}$ : There is a strong and positive relationship between perceived behavioral control and students' entrepreneurial intention.

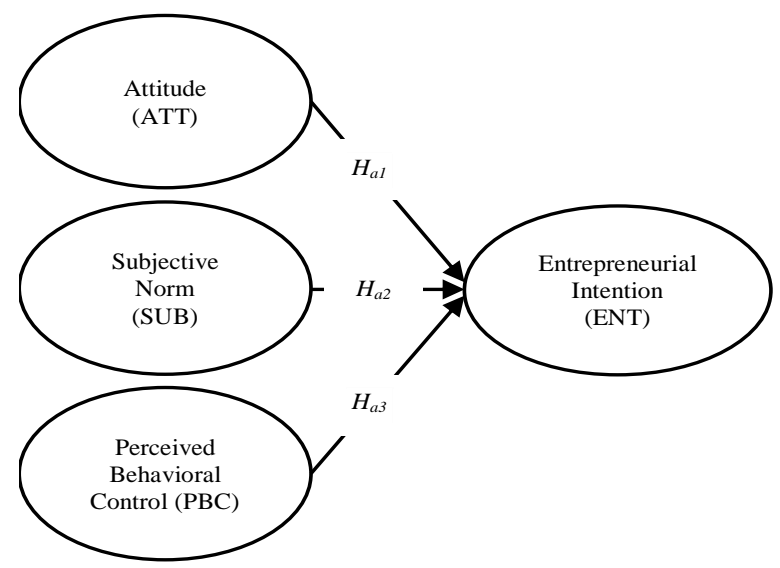

Figure 1. Research hypothesis

\section{Research Method}

This quantitative research was completed by directly distributing questionnaires offline and online to students majoring in management and entrepreneurship in several cities in Indonesia. Students have great potential and a strong tendency to become entrepreneurs in the future (Veciana et al., 2005). The conceptual framework of this research emphasizes students' entrepreneurial intention and personal attraction to entrepreneurship.

\section{Measurement}

Statements were rated using a Likert scale ranging from 1 "Strongly disagree" to 7 "Strongly agree". A measurement scale of 5 or more, as used here, yields better results than scales used below than 5 (Weijters, Cabooter, \& Schillewaert, 2010). The data were analyzed using structural equation modeling. In this study we used AMOS version 24 software to support the model and further analysis.

The preparation of statements referred to several previous studies and adjusted for the Indonesian language as the everyday language used by the respondents. This adjustment aimed to make it easier for the respondents to understand the statements and answer the questionnaires. To measure attitudinal variables, the research instrument used four statements adapted from Solesvik (2013) and Liñán \& Chen (2009). Respondents were asked to assess whether entrepreneurship was considered positive or negative. The instruments used to measure Attitudes are shown in Table 2.

Table 2

Instrument to Measure Attitude

\begin{tabular}{lc}
\hline \multicolumn{1}{c}{ Statements } & Code \\
\hline $\begin{array}{l}\text { Doing business has positive benefits for me. } \\
\begin{array}{l}\text { Doing business is something that I can be } \\
\text { proud of. }\end{array}\end{array}$ & ATT_1 \\
$\begin{array}{l}\text { Starting a business also benefits the } \\
\text { surrounding environment. }\end{array}$ & ATT_3 \\
I have great interest in doing business. & ATT_4 \\
\hline
\end{tabular}

Researcher refers to Solesvik (2013) and Souitaris et al. (2007) to compile statements used in subjective norm. Respondents were asked to assess the influence of their social environment, including family, friends, and others who have a major influence on them in the context of entrepreneurship. Three statements were used to measure the influence of the social environment. The statement instruments used to measure the social environment are given in Table 3.

Table 3

Instrument to Measure Subjective Norm

\begin{tabular}{lc}
\hline \multicolumn{1}{c}{ Statements } & Code \\
\hline $\begin{array}{l}\text { My family hopes that I will become an } \\
\text { entrepreneur. }\end{array}$ & SUB_1 \\
$\begin{array}{l}\text { My closest friend says that I should be an } \\
\text { entrepreneur. }\end{array}$ & SUB_2 \\
$\begin{array}{l}\text { The person I look up to encourages me to } \\
\text { become an entrepreneur. }\end{array}$ & SUB_3
\end{tabular}


The behavioral control variable used three statements adopted from research by Solesvik (2013) and Liñán and Chen (2009). In preparing behavioral control instruments, the challenges in or conveniences of entrepreneurship were emphasized. Respondents were asked to assess how comfortable they are in entrepreneurship. The instruments used are listed in Table 4.

\section{Table 4}

Instrument to Measure Behavioral Control

\begin{tabular}{lc}
\hline \multicolumn{1}{c}{ Statements } & Code \\
\hline $\begin{array}{l}\text { If I want, I can immediately become an } \\
\text { entrepreneur. }\end{array}$ & PBC_1 \\
$\begin{array}{l}\text { When deciding to start a new business, all } \\
\text { decisions are in my hands. }\end{array}$ & PBC_2 \\
I am fully in control of my business. & PBC_3 \\
\hline
\end{tabular}

To measure entrepreneurial intentions, five statements in sequence were used. The statements were created with reference to Solesvik (2013) and Liñán and Chen (2009). Respondents were asked to measure the extent of their intent to pursue entrepreneurship and their personal attraction to entrepreneurship. The statements developed are listed in Table 5.

Table 5

Instrument to Measure Entrepreneurial Intention

\begin{tabular}{ll}
\hline \multicolumn{1}{c}{ Statements } & Code \\
\hline $\begin{array}{l}\text { I will do anything to become an entrepreneur. } \\
\text { I am ready to start a business and ready to run a }\end{array}$ & ENT_2 \\
business now. & \\
If I have the opportunity, I will choose to & ENT_3 \\
become an entrepreneur. & \\
I intend to start a business. & ENT_4 \\
I want to do business as soon as possible. & ENT_5 \\
\hline
\end{tabular}

\section{Results and Discussions}

\section{Data Validity and Reliability}

The distribution of the questionnaire yielded 631 valid questionnaire returns. Table 6 provides validity and reliability measures of the data. To determine the validity and reliability, the data must meet the specified requirements. The greater the calculated value, the greater the data's validity. The validity of the data is measured using average variance extracted (AVE), which must be greater than 0.5. The testing results that met this cutoff are ENT (0.755), PBC (0.742), SUB (0.668), and ATT (0.752).

Next, to measure reliability, the critical ratio (CR) was used. The CR must be greater than 0.7. The test results show that all values exceed the required CR value: IVC (0.913), PBC (0.879), SUB (0.824), and ATT (0.885). Thus, it can be concluded that the data obtained are valid and reliable.

Table 6

Validity, Discriminant Validity, and Reliability Test Results

\begin{tabular}{lcccr}
\hline & ENT & PBC & SUB & \multicolumn{1}{c}{ AT } \\
\hline C.R & 0.913 & 0.879 & 0.824 & 0.885 \\
AVE & 0.755 & 0.742 & 0.668 & 0.752 \\
\hline \hline & PBC & SUB & ATT & \\
\hline PBC & 0.862 & 0.780 & 0.533 & \\
SUB & 0.780 & 0.817 & 0.633 & \\
ATT & 0.533 & 0.633 & 0.867 & \\
\hline
\end{tabular}

Discriminant validity is another tool used to determine the validity of the data. Discriminant validity requires the AVE squared value to be greater than the correlation between different variables. Table 6 confirms this to be the case: The PBC, SUB, and ATT values are $0.874,0.817$, and 0.860 , respectively, whereas the values between different variables are PBC-SUB (0.780), PBC-ATT (0.533), and SUBATT (0.633). Therefore, based on the data testing tools used, it can be seen that the data are valid and reliable to continue to the next testing process.

\section{Goodness-of-Fit Model Index}

The sample size exceeds 400 respondents, thus making the Chi-Square (CMIN) and CMIN/DF scores unsuitable for measuring the fitness of the existing data models (Hair, Black, Babin, \& Anderson, 2014). Although the Chi-Square results are still within the specified range, for our purposes it will be better to use other measurement methods.

Table 7

Goodness-of-Fit Model Index

\begin{tabular}{lcc}
\hline Fit Indicator & Match Level Target & Result \\
\hline$X^{2}$ & $\leq 2-5$ & $X^{2} / d f=3.028$ \\
$N F I$ & $>0.92$ & 0.971 \\
$C F I$ & $>0.92$ & 0.980 \\
$T L I$ & $>0.92$ & 0.974 \\
$R M R$ & $\leq 0.08$ & 0.037 \\
$R M S E A$ & $<0.08$ & 0.057 \\
GFI & $>0.90$ & 0.960 \\
\hline
\end{tabular}

Model accuracy can be measured with the indicators normative fit index (NFI), relative fit index $(R F I)$, comparative fit index $(C F I)$, Tucker Lewis Index (TLI), and goodness of fit index (IFI). These models are confirmed as good if the indicator values are close to 1 . Table 7 shows that the value of the indicators is indeed close to 1 . 


\section{Hypothesis Testing}

Table 8 shows that the ATT and PBC variables have significant influence on the endogenous variable, ENT. The significance of the relationship between SUB and ENT differs from the relationships between other variables and does not meet the significance cutoff $P$-values of $<0.05,0.01$, or 0.001 . SUB and ENT have $P$-value of only 0.172 . When the $P$-value is increased, the relationship between these variables is no longer significant. Thus, it can be concluded that the hypotheses $H_{a 1}$ and $H_{a 3}$ are accepted, whereas $H_{a 2}$ is rejected.

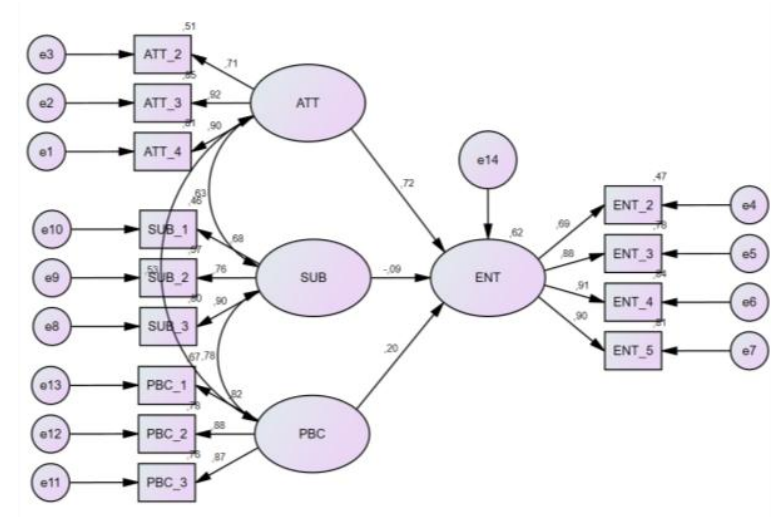

Figure 2. Structural equation modeling output

The results of hypothesis testing show that ATT has a dominant influence on the entrepreneurial of students. The dominance of ATT is expressed by the regression coefficient value of 0.724 toward ENT. This result is followed by PBC, with the resulting coefficient value of 0.204 toward ENT. SUB becomes the variable with the weakest influence, with a coefficient of 0.088 toward ENT. SUB and the endogenous variable, ENT, have an inverse relationship, expressed by the negative sign.

Table 8

Hypothetical Testing Results

\begin{tabular}{cccc}
\hline Hypothesis & Estimate & $\boldsymbol{P}$-value & Decision \\
\hline$H_{a 1}$ & 0.724 & 0.000 & $\mathrm{~S} * * *$ \\
$H_{a 2}$ & -0.088 & 0.172 & $\mathrm{NS}$ \\
$H_{a 3}$ & 0.204 & 0.000 & $\mathrm{~S} * * *$ \\
\hline
\end{tabular}

(S) Supported; (NS) Not Supported

*Significant at 0.05 , or $95 \%$ (two-tailed)

**Significant at 0.01 , or $99 \%$

***significant in 0,001 or $99.9 \%$

\section{Discussion}

Changing circumstances have led to a positive energy toward university students' entrepreneurial intention in Indonesia, viewing it as supporting the economy in a more positive direction (Fayolle \& Gailly, 2004; Kautonen et al., 2015). Since the application of entrepreneurship encouragement, attitude and behavioral control have an important relationship on university students' entrepreneurial behavior. Subjective norm have the opposite relationship, though they were not significant on the students' entrepreneurial intention.

Similar research has showed that attitude and behavioral control are the two indicators that mostly have a positive, significant relationship on entrepreneurial intentions. These results reveal the fact that students' entrepreneurial intention is more reflected by internal factors than by external factors (Paco et al., 2011). Entrepreneurship for students is commonly acceptable and provides positive benefits for students. The same results are also reflected in behavioral control factors having a strong positive influence. Students in this study considered entrepreneurship positively. This indicates that students believe that the challenges faced can be converted into opportunities and that they have a strong intention to become entrepreneurs. However, different results were found for subjective norm, which have the opposite relationship. Several previous studies have confirmed subjecttive norm influence on entrepreneurial intentions (Fayolle \& Gailly, 2004; Florin et al., 2016).

Attitude is an anchor in influencing the entrepreneurial intention of university students. Attitude as represented by instrumental attitude and experiential attitude has a dominant influence. In terms of experiential attitude, the experience of entrepreneurship has a positive impression for university students. The difficulties faced were considered as potentially providing benefits for students (Kusmintarti et al., 2017). From the perspective of instrumental attitude, university students were able to describe the processes, methods, and actions of entrepreneurship as having a good and positive impression (Fayolle \& Gailly, 2015).

The positive response of students from behavioral control indicates that the limitations they face are not significant obstacles. An understanding of entrepreneurship from the examples and theories presented by the surrounding environment could turn challenges into opportunities (Cardon \& Kirk, 2015). Various images of entrepreneurship obtained by students in their environment gave more strength to their intention to become entrepreneurs.

The insignificant relationship in subjective norm indicates that the surrounding environment was not very supportive of students becoming entrepreneurs (Maes et al., 2014; Moriano et al., 2011). Individuals with the closest familial and other relationships affect- 
ing students' lives did not share students' perspective in terms of entrepreneurship, and the views of those in their closest social environment-family, friends, and role models - was not in line with their perceptions. Students' closest social environment considered entrepreneurship negatively and believed that there were other ways for students to be successful. In this line of thinking, entrepreneurship is closely related to uncertainty and does not provide tangible results.

Several studies on entrepreneurial intention have stated that entrepreneurial intention will be more effective if all three factors have a strong and positive influence (Iakovleva et al., 2011; Kautonen et al., 2015). In accordance with the TPB, intention will be influenced by the three factors, including internal, external, and behavioral control as determinant factors of individual decision and the conversion of intention into action.

\section{Conclusion and Recommendation}

Changes in the entrepreneurial environment have provided positive results for university students' entrepreneurship in Indonesia. The attitude factor plays a dominant role in students' entrepreneurial intention. University students have a positive response in entrepreneurial attitudes. Although perceived behavioral control does not contribute as strongly as the attitude factor, it also yields positive and significant relationship. Entrepreneurial encouragement in the environment can translate positively and strengthen students' confidence in their entrepreneurial intention. Subjective norm have no influence on university students' intention in entrepreneurship. However, those in students' social environment express a contrary opinion: To achieve a successful career, students should not be entrepreneurs. According to the nearest social environment, entrepreneurship is highly related to uncertainties and risks, thus making entrepreneurial support difficult to obtain.

The contribution of this research for $T P B$ can enrich the study of entrepreneurial intention in university students and in developing countries such as Indonesia. Differences in these findings compared to previous research can be used to compare the entrepreneurial context from various perspectives. The practical implications of this research can be a reflection of the entrepreneurial situation that occurs in the university students' environment. Positive results from attitude and control factors reflect that entrepreneurship receives a positive response in students' environment. Subjective norm producing the opposite relations can reflect that entrepreneurship is not yet accepted as a way to achieve success, both in the process and the output produced. Discussion of subjective norm is open for future research.

This study has several limitations. The scope of research in a particular area and in a large city is not generalizable to other regions. Therefore, more diverse research is needed to obtain representative results. The data collection method using cross-sectional methods is only able to produce results for a particular time-frame, making it difficult to measure the contribution of environmental changes to each individual. Longitudinal research is open for further discussion.

\section{References}

Ajzen, I. (1991). The theory of planned behavior. Organizational behavior and human decision processes, 50, 179-211.

Ajzen, I. (2005). Attitudes, personality and behavior. Second ed.. Berkshire, England: McGraw-Hill.

Ajzen, I., \& Sheikh, S. (2016). Action versus inaction: Anticipated affect in the theory of planned behavior: Erratum. Journal of Applied Social Psychology, 46(5), 313-314.

Armitage, C. J., \& Conner, M. (2001). Efficacy of the theory of planned behaviour: A meta-analytic review. British Journal of Social Psychology, 40(4), 471-499.

Biraglia, A., \& Kadile, V. (2017). The role of entrepreneurial passion and creativity in developing entrepreneurial intentions: Insights from American homebrewers. Journal of Small Business Management, 55(1), 170-188. doi: 10.1111 /jsbm. 12242

Bird, B. (1988). Implementing entrepreneurial ideas: The case for intention. The Academy of Management Review, 13(3), 442-453. doi: 10.2307/ 258091

Cardon, M. S., \& Kirk, C. P. (2015). Entrepreneurial passion as mediator of the self-efficacy to persistence relationship. Entrepreneurship Theory and Practice, 39(5), 1027-1050. doi: 10.1111/etap. 12089

Fayolle, A., \& Gailly, B. (2004). Using the theory of planned behaviour to assess entrepreneurship teaching programs: A first experimentation. A paper presented in the $4^{\text {th }}$ Annual IntEnt Conference University of Napoli Federico II (Italy), 4-7 July 2004.

Fayolle, A., \& Gailly, B. (2015). The impact of entrepreneurship education on entrepreneurial attitudes and intention: Hysteresis and persistence. Journal of Small Business Management, 53(1), 75-93. doi: 10.1111/jsbm.12065. 
Ferreira, J. J., Matlay, H., Raposo, M. L., Gouveia Rodrigues, R., Dinis, A., \& do Paço, A. (2012). A model of entrepreneurial intention. Journal of Small Business and Enterprise Development, 19(3), 424-440. doi: $10.1108 / 14626001211250$ 144

Florin, J., Karri, R., \& Rossiter, N. (2016). Fostering entrepreneurial drive in business education: An attitudinal approach. Journal of Management Education, 31(1), 17-42. doi: 10.1177/105256 2905282023

Hair, J. F., Black, W. C., Babin, B. J., \& Anderson, R. E. (2014). Multivariate data analysis. Harlow: Pearson Education Limited.

Hunter, S. T., Bedell, K. E., \& Mumford, M. D. (2007). Climate for creativity: A quantitative review. Creativity Research Journal, 19(1), 6990. doi: 10.1080/10400410709336883

Iakovleva, T., Nabi, G., Kolvereid, L., \& Stephan, U. (2011). Entrepreneurial intentions in developing and developed countries. Education + Training, 53(5), 353-370. doi: 10.11 08/0040091111114 7686

Kautonen, T., van Gelderen, M., \& Fink, M. (2015). Robustness of the theory of planned behavior in predicting entrepreneurial intentions and actions. Entrepreneurship Theory and Practice, 39(3), 655-674. doi: 10.1111/ etap.12056/abstract

Kolvereid, L. (1996). Organizational employment versus self-employment: Reasons for career choice intentions. Entrepreneurship Theory and Practice, 20(3), 23-31.

Kristiansen, S., \& Indarti, N. (2004). Entrepreneurial among Indonesian and Norwegian students. Journal of Enterprising Culture, 12(1), 55-78.

Krueger, N., \& Brazeal, D. (1994). Entrepreneurial potential and potential entrepreneurs. Entrepreneurship Theory and Practice, 18 (3), 91-104

Krueger, N., Reilly, M., \& Carsrud, A. (2000). Competing models of entrepreneurial intentions. Journal of Business Venturing, 15(5-6), 411432.

Kusmintarti, A., Asdani, A., \& Riwajanti, N.I. (2017). The relationship between creativity, entrepreneurial attitude and entrepreneurial intention (Case study on the students of State Polytechnic Malang). International Journal of Trade and Global Markets, 10(1), 28-36. doi: 10.1504/ ijtgm.2017.082379

Küttim, M., Kallaste, M., Venesaar, U., \& Kiis, A. (2014). Entrepreneurship education at university level and students' entrepreneurial intentions. Procedia - Social and Behavioral Sciences, 110, 658-668. doi: 10.1016/j.sbspr 0.2013.12.910
Leroy, H. L., Maes, J., Sels, L., \& Meuleman, M. (2009). Gender effects on entrepreneurial intentions: A tpb multi-group analysis at factor and indicator level. A paper presented at the Academy of Management Annual Meeting, 711 August 2009, Chicago (Illinois, USA)

Liñán, F., \& Chen, Y. W. (2009). Development and cross-cultural application of a specific instrument to measure entrepreneurial intentions. Entrepreneurship Theory and Practice, 33(3), 593-617.

Liñán, F., Rodríguez-Cohard, J., \& Rueda-Cantuche, J. (2011). Factors affecting entrepreneurial intention levels: A role for education. International Entrepreneurship and Management Journal, 7, 195-218.

Maes, J., Leroy, H., \& Sels, L. (2014). Gender differences in entrepreneurial intentions: A tpb multigroup analysis at factor and indicator level. European Management Journal, 32 (5), 784 794. doi: 10.1016/j.emj.2014.01.0 01

Moriano, J. A., Gorgievski, M., Laguna, M., Stephan, U., \& Zarafshani, K. (2011). A cross-cultural approach to understanding entrepreneurial intention. Journal of Career Development, 39(2), 162-185. doi: 10.1177/0894845 310384481

Nishimura, J. S., \& Tristán, O. M. (2011). Using the theory of planned behavior to predict nascent entrepreneurship. Academia, Revista Latinoamericana de Administración, 46, 55-71.

Obschonka, M., Silbereisen, R. K., \& Schmitt-Rodermund, E. (2010). Entrepreneurial intention as developmental outcome. Journal of Vocational Behavior, 77(1), 63-72. doi: 10. 1016/j.jvb.2010. 02.008

Paco, A. D., Ferreira, J., Raposo, M., Rodrigues, R. G., \& Dinis, A. (2011). Entrepreneurial intention among secondary students: Findings from Portugal. International Journal of Entrepreneurship and Small Business, 13(1), 92. doi: 10.1504/ ijesb.2011.040418

Peng, Z., Lu, G., \& Kang, H. (2012). Entrepreneurial intentions and its influencing factors: A survey of the university students in Xi' an China. Creative Education, 03(08), 95-100. doi: 10.4236/ce. 2012.38B021

Peterman, N., \& Kennedy, J. (2003). Enterprise education: Influencing students' perceptions of entrepreneurship. Entrepreneurship Theory and Practice, 28(2), 129-144

Sheppard, B., Hartwick, J., \& Warshaw, P. (1988). The theory of reasoned action: A meta-analysis of past research with recommendation for modifications and future research. The Journal of Consumer Research, 15(3), 325-343. 
Solesvik, M. Z. (2013). Entrepreneurial motivations and intentions: Investigating the role of education major. Education + Training, 55 (3), 253-271. doi: 10.1108/00400911311309 314

Souitaris, V., Zerbinati, S., \& Al-Laham, A. (2007). Do entrepreneurship programmes raise entrepreneurial intention of science and engineering students? The effect of learning, inspiration and resources. Journal of Business Venturing, 22(4), 566-591. doi: 10.101 6/j.jbusvent.2006.05.002

Townsend, D. M., Busenitz, L. W., \& Arthurs, J. D. (2010). To start or not to start: Outcome and ability expectations in the decision to start a new venture. Journal of Business Venturing, 25(2), 192-202. doi: 10.1016/j.jbusve nt.2008.05.003

Turker, D., \& Selcuk, S. S. (2009). Which factors affect entrepreneurial intention of university students? Journal of European Industrial Training, 33(2), 142-159. doi: 10.1108/030905909 10939049

Urbano, D., \& Aparicio, S. (2016). Entrepreneurship capital types and economic growth: International evidence. Technological Forecasting and Social Change, 102, 34-44.
Veciana, J. M., Aponte, M., \& Urbano, D. (2005). University students' attitudes towards entrepreneurship: A two countries comparison. International Entrepreneurship and Management Journal, 1(2), 165-182.

Weijters, B., Cabooter, E., \& Schillewaert, N. (2010). The effect of rating scale format on response styles: The number of response categories and response category labels. International Journal of Research in Marketing, 27(3), 236-247. doi: 10.1016/j.jiresmar.201 0.02.004

Zhang, Y., Duysters, G., \& Cloodt, M. (2013). The role of entrepreneurship education as a predictor of university students' entrepreneurial intention. International Entrepreneurship and Management Journal, 10(3), 623-641. doi: 10.1007/ s11365-012-0246-z

Zhao, H., Seibert, S. E., \& Hills, G. E. (2005). The mediating role of self-efficacy in the development of entrepreneurial intentions. J Appl Psychol, 90(6), 1265-1272. doi: 10.10 37/00219010.90.6.1265. 